\title{
天然ゴム生産植物乳管細胞のバイオイメージング
}

\author{
中 澤 慶 久
}

\section{Bioimaging of the Lactiferous Cells in Rubber Production Plants}

Yoshihisa NAKAZAWA (Hitz Collaborative Research Institute, Graduate School of Engineering Osaka University, 2-8 Yamadaoka, Suita, Osaka 565-0871, Japan) nakazawa@bio.eng.osaka-u.ac.jp

Production of natural rubber is a kind of bio-industry which needs large scale plantation, a huge sum of money and assets/The more latex be produced from natural rubber plants with high polyisoprene content, the more advancement of production are needed to improve the cost-performance financially. Then, in order to improve the production of plantation, the process of selection breeding and cultivation has been continuing for over 150 years. Since the natural rubber industry depends on the bioresource of plants, the improvement of production will be an industrial theme forever.

Natural rubber tree has a special organ named lactiferous cell which synthesizes and accumulates hydrophobic compound.This report gained a bio imagine of lactiferous cell of two kinds of natural rubber plants by using articulate lactiferous cell localized in Para rubber trees (Hevea brasiliensis Muell. Arg.) of cis-polyisoprene and phloem localized as crystallized polymer in Hardy rubber trees (Eucommia ulmoides Oliver) of trans-polyisoprene. From this result, we introduce the sink and source relationship needed to improve the natural rubber plants production and research the morphological characters of lactiferous cell which stores polyisoprene, a kind of unproductive compound to plants.

(Received on March 7, 2018)

Key Words : Bioimaging, Lactiferous Cells, Hevea, Eucommia.

\section{1. はじめに}

天然ゴムの生産には大規模なプランテーションが必要で あり，巨額な資金と資産を必要とするバイオマス産業であ る. 天然ゴム生産の資源植物の必要条件として，ポリイソ プレン（PI）の含有量が高く，ラテックスなどの産出量が 多いほど優良系統とされる。すなわち，バイオマスとして のコストパフォーマンス向上を目的とした生産量向上が経 済的に求められている。 そして，プランテーションにおけ る産出量を高めるために, パラゴムノキでは 150 年以上に わたり品種改良や栽培法の改良が現在でも続けられてい る.しかし, 天然ゴム産業が植物バイオマスのシンクとソー スに依存している限り産出量の増加は産業上永遠のテーマ となっている。
天然ゴム生産植物には乳管細胞というPIなどの毒性のあ る疎水系化合物を生合成押よび蓄積する異形化した特殊器 官を有している．天然ゴム生合成のメカニズムを理解し， 生産性の向上を図るには生合成器官である乳管細胞の構造 の理解が課題である. すなわち, 乳管細胞の発生数の多さ と乳管細胞の発達程度が天然ゴムの生産量に直接関与して いる.

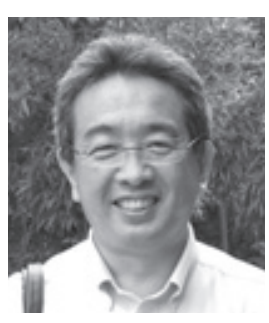

中澤 慶久; 大阪大学大学院工学研究科 Hitz協働研 究所特任教授 ( ⿳5 565-0871 大阪府吹田市山田丘 2-8 テクノアライアンス棟 8 階) 所長, 博士 (農学) 九 州大 1998 年. 1988年, 九州東海大学大学院農学研究 科遺伝育種専攻終了. 1986年, 日立造船(株機能性材 料事業推進室参事休職 (2005年より大阪大). 専門 は, 木質科学 園芸科学 遺伝育種科学 細胞生物学 作 物生产科学 天然資源系薬学 高分子. 繊維材料 生物 機能・バイオプロセス 社会学. 中国ゴム協会杜仲ゴ 么研究会特別教授ほか. 
本報告では, Hevea brasiliensis（パラゴムノキ）のラテッ クスに含まれるシス型PI（CPI）を産出する師部組織の有 節乳管細胞について, 発生から消滅するまでの形態学的な 変化を紹介する．また，Eucommia ulmoides（トチュウ） に含有する結晶性ポリマーとして代謝されるトランス型PI (TPI) の師部組織を対象材料とした無節乳管細胞の発生か ら TPIの蓄積機序を紹介する。この 2 種類の天然ゴム産生 植物に関わる師部組織の乳管細胞について, バイオイメー ジングによる乳管細胞の発生から機能停止までの顕微化学 的変化を取得した。この成果から, 天然ゴム生産植物にお けるPI含有量を高めるために必要なシンクとソースの関係 を紹介し, 植物にとって非生産的な化合物であるPIを貯蔵 する乳管細胞の形態学的特徵について考察する.

\section{2. パラゴムノキ乳管細胞のバイオイメージング}

同種は，年間1千万トン超のCPIを含む天然ゴムを生産 する植物資源である。天然ゴム産業は夕イヤ産業に代表さ れる巨大企業が営む産業であり戦略物質でもある。同種は 東南アジアにて 150 年以上前から天然ゴムの生産性を高め る品種改良や生産技術開発を行っており，野生種よりはる かに生産性を高めてきた. しかし，未だに育種の途上にあ る. 同種のラテックス生産性が高まれば農園のコストの改 善となり, 労働集約型の天然ゴム産業の全体の向上につな がる。

パラゴムノキの乳管細胞の局在する師部組織の構造は, 1912年にMeunier ${ }^{1)} に よ り$ 光学顕微鏡で最初に観察された. その後, Vischer (1923) ${ }^{2)}$, Riches と Gooding (1952) ${ }^{3)}$, Nicole et al. (1986） ${ }^{4)}$ らによりスケッチによる三次元構造の模式 図を示しているが, これらは実体像を示すものではなく， 詳細な乳管細胞のネットワーク構造は不明暸であった。産 業上重要な植物でありながら, 成熟産業となっているなど の理由から，ラテックス生産器官の乳管細胞を手掛ける研 究例が少なくなっていた。 そこで，既報告（Sando et al. 2009） ${ }^{5)}$ した顕微化学にアレンジを加えて再考した乳管細 胞のバイオイメージングについて紹介する.

\section{1 材料および方法}

供試したパラゴムノキはブリヂストン(株)のプランテー ションPTPN VIII (Cikumpay, Purwakarta, West Java, Indonesia）で栽培された 10 年生の優良系統 (Clone RRIM600)より採取した直径約 $60 \mathrm{~mm}$ の幹とラテックスを 組織観察に供した。組織観察用サンプルは，パラゴムノキ 幹をサンプリング後，現地にて表皮，師部組織，形成層と 少量の木部を含む約 $5 \mathrm{~mm}$ 角のブロックを作製した。 その 後, ブロックをTissue-Tek ${ }^{\circledR}$ OCT compound（Sakura Finetek, Tokyo, Japan）に包埋し, 液体窒素を用いて瞬 間凍結させた．組織切片の作製は，刃 刃EICA818（Leica， Germany）を装着したクライオスタットCM-1850（Leica）
を用いて, 凍結ブロックより $-20{ }^{\circ} \mathrm{C} て ゙$ 生組織切片を作製し た. 横断面, 縦断面の組織観察には $40 \mu \mathrm{m}$ 厚とした。接線 断面方向の乳管細胞の観察には横断面の切片を作製し, 乳 管細胞を確認後ブロックの方向を変え，表皮から形成層方 向に60 $\mu \mathrm{m}$ 厚の連続切片を作製した. 組織切片の染色は, 前述の方法にて作製した切片をスライドグラス上に移動さ せ, 蒸留水を用いて OCT compoundを除去した. $50 \mu \mathrm{g} / \mathrm{ml}$ Nile red (Molecular Probes, Eugen, OR) in 50\% ethanol を用いて 5 秒間染色後, 蒸留水を用いて水洗した。対比染 色として $1 \mathrm{mg} / \mathrm{ml}$ Fluorescent Brightener 28 (FB28) (Sigma-Aldrich） in distilled waterを用いて10秒間染色するこ とにより細胞壁を染色した。 耐蛍光封入剂 VECTASHIELD ${ }^{\circledR}$ Mounting Medium (Vector Laboratories, Burlingame, CA, USA）により封入した. 標準品のラテック スは乾燥後, Nile red (Molecular Probes) にて染色した.

\section{2 イメージング画像の取得}

スペクトル共焦点レーザ顕微鏡（SCLSM） DIGITAL ECLIPSE C1si（Nikon, Tokyo, Japan）を使用した. 対 物レンズCFI Plan Apo10×, $20 \times, 40 \times, \mathrm{VC} 100 \times \mathrm{H}$, ソフトウェア EZ-C1 3.40 software (Nikon) を用いて染色 後の切片の観察を行った. 蛍光観察の際の励起には405 nm のダイオードレーザ $(17 \mathrm{~mW}), 488 \mathrm{~nm}$ の固体レーザ $(20$ $\mathrm{mW}$ ）を使用し, レーザパワーは $1.0-5.0 \%$ に設定した. 32 マルチチャンネルにて画像を取得し, 波長分解能 $10 \mathrm{~nm}$ で $423-743 \mathrm{~nm}$ の波長領域の蛍光検出を行った. $1024 \times 1024$ ピクセルで画像を取得し, S/N 比向上のため 3 回の画像を 取得してノイズ等の平均化を行った。画像解析に使用する 解析用の三次元像の構築に使用する画像は $512 \times 512$ ピクセ ルで, 2 回の画像を取得した。

CPIなど目的化合物のリファレンススペクトルデータ （RSD）の取得は, 細胞構成物, 細胞内容物をしめす関心領 域（ROIs）を指定し, 領域内の蛍光スペクトルを取得した. 単染色した切片もしくはラテックスを使用し, 高解像度 $(1024 \times 1024$ ピクセル, 10 回スキャン, 波長分解能 $5 \mathrm{~nm})$ で取得した画像上の30箇所の領域の蛍光スペクトルを平均 化することにより, 後の蛍光分離に使用する RSD を取得し た。

蛍光分離と三次元構築は, 取得した画像に対し, EZ-C1 3.40 software（Nikon Instruments）を用いて蛍光分離を 行った. 蛍光分離には上記の方法で取得したRSDを使用し た（Nile red スペクトル [最大蛍光波長 $547 \mathrm{~nm}, 575 \mathrm{~nm}$ ], FB 28 スペクトル [最大蛍光波長 $444 \mathrm{~nm}$ ]). 三次元画像の 構築はScan Range 20 - $50 \mu \mathrm{m}$, Step Size $0.35-1.00 \mu \mathrm{m}$ の条件で連続的に取得した40-150枚の画像を蛍光分離後, ボリュームレンダリングすることにより作製した（ spin 0 deg. tumble 0 deg. method maximum).

画像解析は, NIS-Elements AR software（Nikon）を用 
いて行った。測定は同一切片上で無作為に選択した8箇所 に対し層別に行った．乳管細胞の穿孔数を層別に計測する 画像測定機能を用いて，画像上の乳管細胞の長さと穿孔数 を測定した。乳管細胞とそれ以外の組織の面積比率を計測 するために，まず上記の方法で構築した三次元画像より， 乳管細胞のみを抽出し,グレースケールに変換した. Object Count機能を用いて, 輝度值50-255における乳管細胞と それ以外組織の面積を層別に測定した。同様の方法で，乳 管細胞に囲まれている放射細胞の面積を 100 区画層別に測 定した

\section{3 結果および考察}

\section{3.1 バイオイメージングの取得}

当該研究に用いたSCLSM C1si は, 蛍光の波長情報を取 得でき，重複したスペクトルを分離できる．ラテックスの 蛍光特性を調べるため, Nile redで染色した乾燥ラテック スと師部組織の接線断面切片を作製した。また，細胞壁の セルロース特異的蛍光プローブであるFB28で染色した接 線断面切片を作製した. SCLSMを用い, ラテックス, 細胞 内の粒子状脂溶性物質, 細胞壁のそれぞれを関心領域 （ROI）指定し, RSDを取得した（図1A）。それぞれの最大 蛍光波長は, ラテックス：547 nm（Nile red）, 粒子状脂溶 性物質：567 nm (Nile red)，細胞壁：442 nm（FB28）で あった. Nile red染色したラテックスと粒子状脂溶性物質 の蛍光スペクトル間において, $20 \mathrm{~nm}$ の最大蛍光波長の差 と波形が異なることが認められた，SCLSMを用い， Nile redのラテックス特異的な蛍光を分離できることが判明し た（図1A）。師部組織の横断面切片を作製し， Nile redお
よびFB28で二重染色して, SCLSMを用いて蛍光スペクト ルを取得した，取得したRSDを用い，ラテックスのスペク トルを赤色, 粒子状脂溶性物質のスペクトルを青色, 細胞 壁のスペクトルを緑色に指定し, 蛍光分離処理によるバイ オイメージング画像を得た（図1B）。それぞれの蛍光スペ クトルの抽出により, ラテックス (赤色), 粒子状脂溶性物 質 (青色)，細胞壁（緑色）を分離できた（図 1C-E). Nile red染色した師部組織において, SCLSMを用い蛍光分離す ることにより乳管細胞の画像を抽出し, 詳細な構造解析が 可能となった.

\section{3.2 パラゴムノキ乳管細胞の形態}

De Barry (1884） ${ }^{6)}$ は, 乳管細胞を無節乳管細胞と有節 乳管細胞の二つの主なタイプに分類している. そして, Fahn (1979） ${ }^{7)}$ は無節乳管細胞は, 分裂組織内に一つの細 胞として現われ，速やかに伸長し，その先端は周囲の細胞 間を縫って成長し，分枝して植物体のすべての組織に及ぶ とされる。一方, 有節乳管細胞は, 分裂組織内に細胞の縦 列としてあらわれ，発生の初期に，それらの細胞間の隔壁 の一部または全部が消失して管状と定義している．XiuQian $(1987)^{8)}$ は，パラゴムノキには無節乳管細胞と有節 乳管細胞の両方が存在し, 前者は子葉, 葉, 花, 果実, 根, 茎に存在し，後者は樹皮の二次師部内に存在することを報 告している.

今回取得したバイオイメージング画像は, 図 $2 \mathrm{~A} の$ 乳管 細胞相互の横の連絡としての穿孔が形成され, 網状の構造 であり，既知報告と同様に，師部組織に有節乳管細胞の局 在がみられた。ささらに, 接線断面切片の蛍光分離画像から
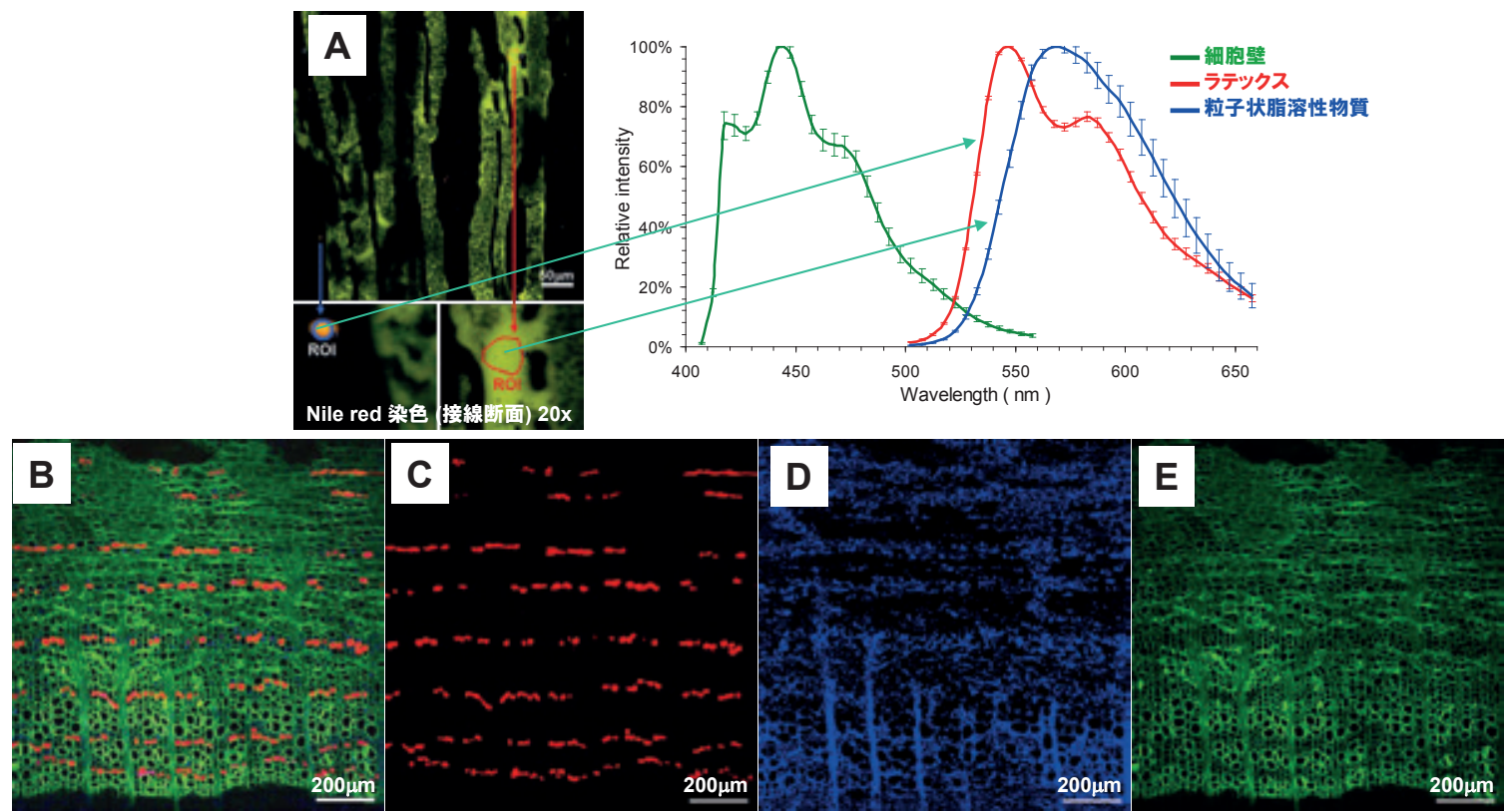

図 1 パラゴムノキ師部組織のバイオイメージング

$\mathrm{A}$ ：蛍光分離 ROI指定

$\mathrm{B}$ ：蛍光分離画像：赤色, 粒子状脂溶性物質 : 青色, 細胞壁 : 緑色

$\mathrm{C}$ : ラテックス抽出画像, $\mathrm{D}$ ：粒子状脂溶性物質抽出画像, $\mathrm{E} ：$ 細胞壁抽出画像

Reprinted with permission form Planta 230, 215, (2009). Copyright 2009 Springer International Publishing AG. 


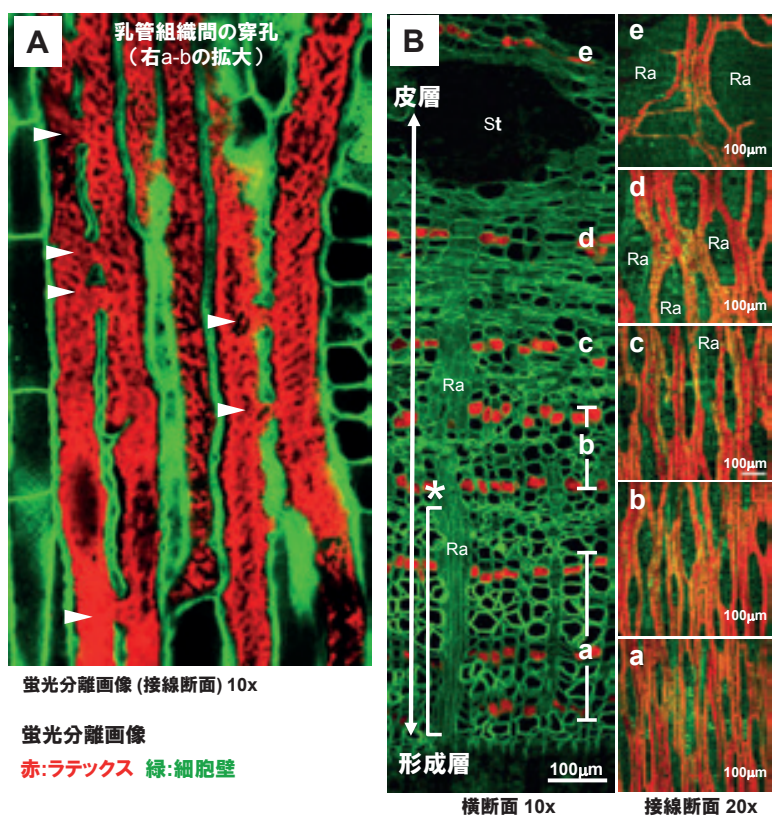

図2 パラゴムノキ接線面の有節乳管細胞の形態

$\mathrm{A}$ ：有節乳管細胞間に形成される穿孔（ラテックス：赤色, 細胞壁 緑色)

$\mathrm{B}$ ：横断面の蛍光分離画像 (ラテックス : 赤色, 細胞壁 : 緑色

$\mathrm{a}-\mathrm{e}$ : 接線断面層別の乳管細胞の構造

蛍光分離後に三次元構築した画像

(形成層側より：a層, b 層, c 層, d 層, e 層),

$\mathrm{Ra}$ : 放射組織, St：石細胞

Reprinted with permission form Planta 230, 215, (2009). Copyright 2009 Springer International Publishing AG.

師部の纎維組織近傍に，無節乳管細胞が同調して多数存在 していることを観察した（図2B）。また，師部の縦断面切 片の蛍光分離画像より，放射組織の分裂生長，および樹皮 側に近い師部の石細胞の形成により，乳管細胞や師管の縦 方向の連続性の崩壊を観察した。一般にパラゴムノキの タッピング断面において，ラテックスは形成層側の断面か ら大量に流出し，師部中央部から樹皮側には流出が見られ ない(外皮側から少量流出)。これは今回の結果と同じく， 樹皮側に向かい乳管細胞の構造的な崩壊がラテックスの産 出量に直接影響していると考察する.

形成層より同調して分裂する乳管細胞の構造変化につい て, Hebant $(1981)^{9)}$ は, 樹皮内の乳管組織の電子顕微鏡 による観察で，隣接した乳管細胞間において穿孔の存在を 報告している。 また, Frey-Wyssling (1930) ${ }^{10)}$ は, ラテッ クス低産生の木に扔いて，乳管細胞は連続せず，多くの管 が袋小路状である．ラテックス高産生の木では乳管細胞が 連続すると報告している。しかし，これまでパラゴムノキ において同調に分裂した乳管細胞の構造に着目した観察例 はなかった，そこで，層別の乳管細胞の構造変化を明らか にするために，乳管細胞の接線断面切片を作製した，バイ オメージングの取得は上述と同じで三次元画像を構築した (図 $2 \mathrm{~B}, \mathrm{a}-\mathrm{e}$ ).

形成層から $2 \sim 3$ 層目の乳管細胞が位置する領域は，師
管が明瞭に観察でき，師部組織が機能している (図 2Ba). この領域をConducting phloemと呼ぶ. Conducting phloem 内の乳管細胞は，幅が狭く，他の乳管細胞の層に比べて隣 接した乳管細胞間の間腺が大きいこと, 円錐状の乳管細胞 の末端構造が多数存在することが明らかとなった（図 2Ba）。また，これらの有節乳管細胞の末端構造は, 次の層 において, 複数の穿孔により癒着し、ネットワーク構造の 一部になることを確認した（図 $2 \mathrm{~A}$ )。乳管細胞を分裂層別 に観察した結果，形成層から樹皮に向かい乳管細胞間の穿 孔数が増加する傾向が観察された (図 $2 \mathrm{Ba}-\mathrm{e})$. 画像解析 から隣接した乳管細胞間に形成される穿孔数を層別に求め た結果を, 図3Aに示した. Conducting phloem内の乳管細 胞（a）は, 乳管細胞間の穿孔数が少なく, 形成層から樹皮 側に向かい, 乳管細胞間の穿孔数の有意な増加を確認した。 ラテックス高産生クローンほど, 乳管細胞の末端構造の消 失と穿孔数の増加が顕著となり, ネットワーク構造が発達 していると考察した.

乳管細胞の機能停止は，これは形成層から樹皮側への放 射組織の分裂生長により乳管細胞のネットワークに打ける 放射組織発達に由来する (図 $2 \mathrm{Bc}-\mathrm{e}$ )。乳管細胞は, 分裂 生長しないため, パラゴムノキの生長（放射組織の分裂生 長と横方向の張力）により最終的に崩壊する.

この証明のため蛍光分離により乳管細胞の画像を抽出 し, 乳管細胞とそれ以外の組織が占める面積比率を層別に 計算した結果を図3Bに示した。乳管細胞は, Conducting phloem 内から次層にかけて増加するが, 形成層から樹皮に 向かい面積が減少した，対照的に, 乳管細胞以外の組織は 樹皮側に向かい面積が増加した。

Hebant（1980） ${ }^{11)}$ は, 乳管細胞における天然ゴム合成に 必要な代謝物の供給に放射組織が重要な働きを報告してい る.しかし，今回の観察では放射組織の分裂生長が原因と なり, 乳管細胞の穿孔，すなわち横方向のネットワーク構
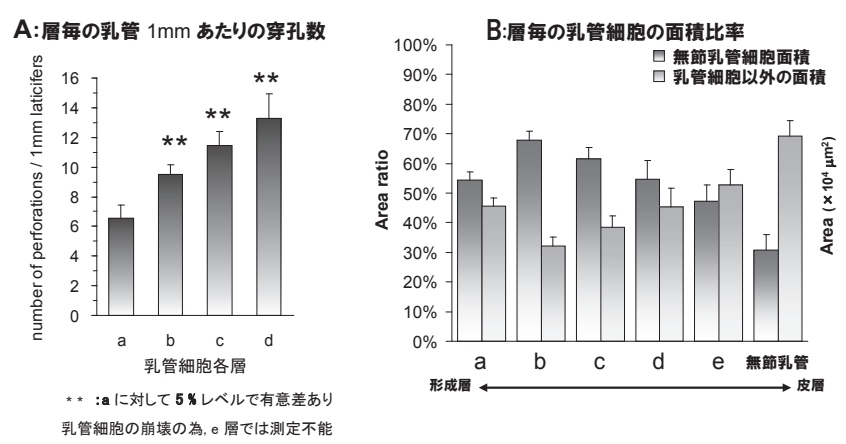

図 3 パラゴムノキ乳管細胞の穿孔数および乳管細胞面積の変化

$\mathrm{A}$ ：形成層分裂組織から発生した層毎の有節乳管細胞 $1 \mathrm{~mm}$ あたりの 穿孔数

**はaに対して $5 \%$ レベルで有意差あり e, fは乳管細胞崩壊のため測定 不能

$\mathrm{B}$ ：層毎の乳管細胞と放射組織の面積変化

Reprinted with permission form Planta 230, 215, (2009). Copyright 2009 Springer International Publishing AG. 
造が崩壊し，ラテックス生合成機能が消失すると推測され た.

\section{4 パラゴムノキ乳管細胞の考察}

Nile red とSCLSMを組み合わせた乳管細胞のバイオイ メージングの開発により，パラゴムノキにおけるラテック ス生産乳管細胞の構造を把握することに成功した. ラテッ クスを高効率で生産する乳管細胞とは，有節乳管組織とな り形成層にて層別に同調した乳管細胞が連続的に形成さ れ, 乳管細胞の同調数の増加がラテックス高収量につなが る因子であることが判明した。また，連結乳管組織の結合 部数なども立体的に複雑な乳管ネットワークの存在が判明 している. 現在は, ラテックス収量と乳管細胞構造の相関 について調査しており，ラテックス多収量品種選抜の計測 手段のひとつである。 この手法は, 天然ゴム産生能の高い パラゴムノキをはじめとするラテックス高生産個体のスク リーニングや, プランテーションの生産能力増強に関わる 有用な評価技術である.

人類は約 150 年の時間を費やして，ラテックス生産を高 める品種改良を進めてきた。この求めてきた生物学的な結 論として，パラゴムノキをはじめとするラテックス生産植 物の有節乳管細胞の穿孔数の多さと同調分裂数の増加が重 要であり, 師部組織内における充実した乳管細胞ネット ワーク構造を構築していることだと考察する.

\section{3. トチュウ乳管細胞のバイオイメージング}

Eucommia ulmoides（トチュウ）は, 温帯圈荒地の未利 用地にて生育可能な植物種であり, 生薬原料以外に全草の L2層にTPIを生産する植物として知られている。 トチュウ に含まれるTPIは結晶性ポリマーであり, その分子量は 100 万超の高分子である. 樹皮や種子の無節乳管細胞に蓄積さ れ，L2層の組織を引き裂くと糸状の TPIを観察することが できる，糸状に見えるのは単乳管細胞に蓄積されたTPIで あり，乳管細胞のレプリカとして目視観察できることが卜 チュウの特徴である.

トチュウ由来のTPIは国内企業や中国ゴム協会を市場供 給する目的で事業を行っている. ナフサ起源とする TPIに 比較すると分子量分布領域がシャープであり中間体が存在 しないという特徴がバイオ由来でも利用価值に值すると考 えられる.

著者ら (2012） ${ }^{12)}$ は, トチュウのTPIに関わる生合成遺 伝子の解析に取り組み, TPIを合成する遺伝子群を発見し TIDSと名付けた。この遺伝子は既知のファルネシル 2 リ 酸合成酵素の一部にアミノ酸の変異が生じたもので, 基質 を重合して疎水系のTPIに重合させる炭化水素重合遺伝子 として注目されている。 この酵素の発現については別の機 会に紹介したい.

パラゴムノキと同様にトチュウにおいても TPI増量に関
する品種改良が重要となっている。現在, 品種改良は著者 や中国林業科学院により野生種からの選抜育種がなされて いるが, TPI量産化を図るためには, トチュウの乳管細胞 に関する詳細な観察方法が必要であった. 本項では, トチュ ウの無節乳管細胞に関するバイオイメージングについて既 知（著者ら 2013） ${ }^{13 ）}$ 情報を再編して紹介する.

\section{1 実験材料および方法}

トチュウの当年枝は広島県尾道市因島中庄内町より 9 月 に採取した。当年枝には, 二次組織が発達する前の直径 5 $\mathrm{mm}$ 程度の柔らかい幼茎と, 二次組織が形成された直径 20 $\mathrm{mm}$ 程度の硬い茎を用いた. RFDのTPIは生薬用杜仲樹皮 を用い, 中国四川省生薬市場にて入手した.

実験方法は, SCLSM 組織観察は2.1の項目に準じ, ト チュウ乳管細胞のバイオイメージングを取得した. Nile red染色されたTPI, 粒子状脂溶性物質およびFB28染色さ れた細胞壁を ROI指定し, それぞれ10箇所より取得した蛍 光スペクトルを平均した。乳管細胞内のTPI観察は, ウル トラミクロトーム（LKB8800 [LKB]）で超薄切片（厚さ 80 ～ $90 \mathrm{~nm}$ ) を作製し, 透過型電子顕微鏡（JOEL JEM1200EX加圧電流 $80 \mathrm{kV}$ ) を用いて, トチュウ当年枝の師 部組織に分布する無節乳管細胞内の TPIの局在状況を観察 した。

\section{2 結果と考察}

\subsection{1 バイオイメージングの取得}

生薬用のトチュウ樹皮から TPI繊維状物質を Nile redで 染色し, SCLSMで蛍光スペクトルのROIを測定（最大蛍 光波長： $545 \mathrm{~nm}$ ) しRFDとした（図 4A)。師部組織の横 断面切片を作製しSCLMSにより蛍光分離処理を行い, 450 $\mathrm{nm}$ のピークを青色, $545 \mathrm{~nm}$ のピークを黄色, $575 \mathrm{~nm}$ の ピークを赤紫色に指定し, 蛍光分離画像を得た (図4B). そ れぞれの蛍光スペクトルの抽出により, TPI : 黄色, 粒子 状脂溶性物質: 赤紫色, 細胞壁: 青色を分離できた（図4 C-E). Nile red染色した組織において, SCLSMを用い蛍光 分離することにより TPIの画像を抽出し, 詳細な画像解析 が可能となった。

\subsection{2 トチュウ乳管細胞の形態}

樹皮師部横断面のバイオイメージングを取得した. 黄色 のシグナルで示される TPIは皮層と師部の組織間に存在し た (図5A)。これはWeissら (1892） ${ }^{14)}$ の観察結果と一致 している。ささに，拡大像を観察したところ，形成層近傍 の若い二次師部には, 顆粒状のTPIの蓄積が見られた（図 $5 \mathrm{C})$. 一方で, 形成層から表皮側へと移行した古い二次師 部では, 繊維状のTPIの切断面を観察した（図5B）.

天然ゴム産出植物は化学構造の幾何異性体 (CPI, TPI) に関係なく，ラテックスと称す乳液状のPIを産出する $\mathrm{Ke}-$ kwick (2001) ${ }^{15)}$ 。 ラテックスは乳管細胞にラバーパーティ クル $(\mathrm{RP})$ として細胞質に分散したエマルジョンを形成し 

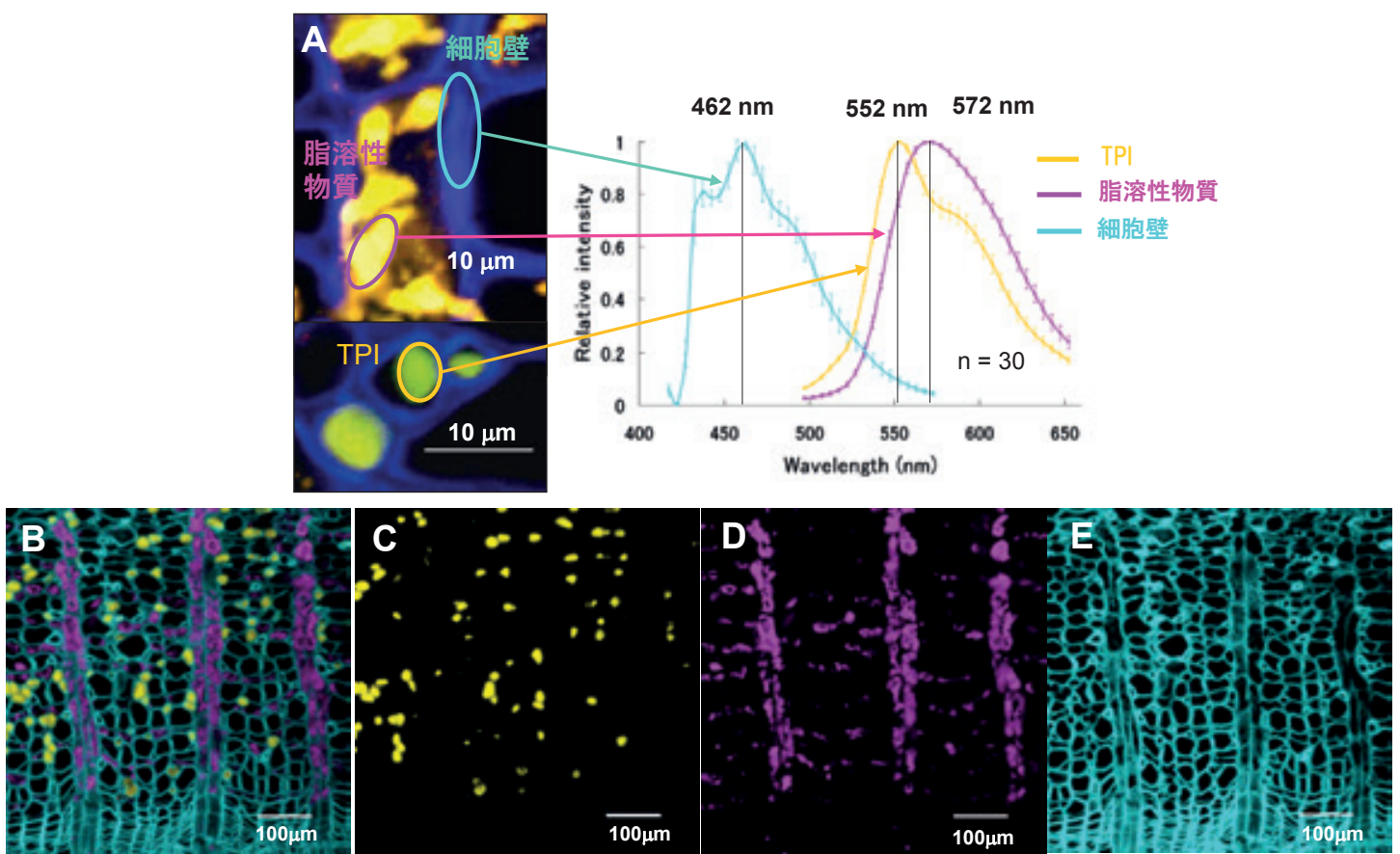

図4 トチュウ師部組織のバイオイメージング

$\mathrm{A}$ ：蛍光分離 ROI指定,

$\mathrm{B}$ ：蛍光分離画像; TPI : 黄色, 粒子状脂溶性物質 : 赤紫色, 細胞壁 : 青色

C : TPI 抽出画像, D : 粒子状脂溶性物質抽出画像, E : 細胞壁抽出画像

Reprinted with permission form Planta 238, 549, (2013). Copyright 2013 Springer International Publishing AG.
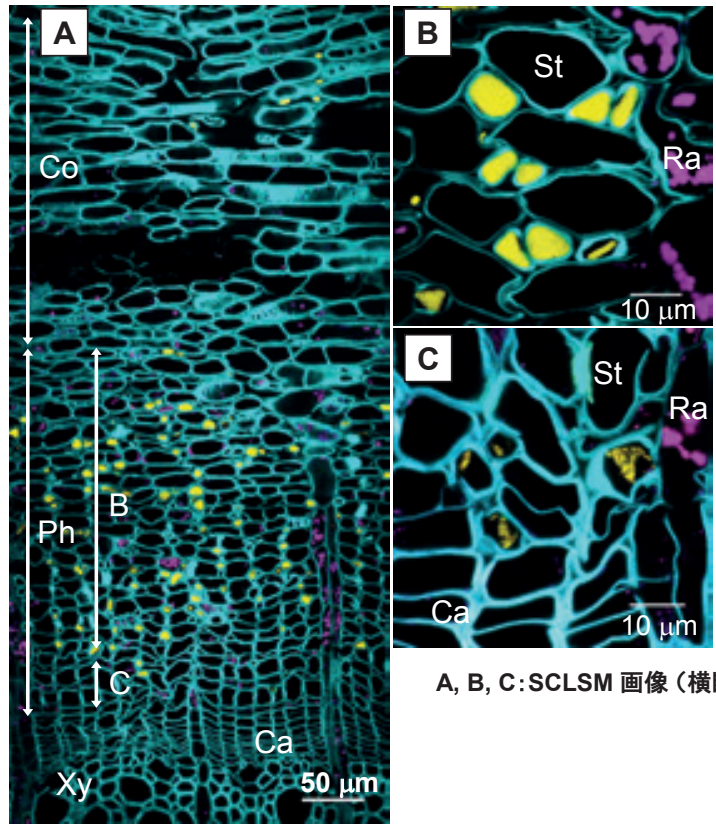

A, B, C:SCLSM 画像 (横断面)

図5 トチュウ師部の横断面の TPI局在

$\mathrm{A}$ : 形成層から表皮まで師部横断面全体の蛍光分離画像TPIが皮層お よび師部組織に局在

B：形成層から表皮側へと移行した二次師部の蛍光分離画像形成層か ら離れた二次師部でTPIが均一な固形状物質として存在

$\mathrm{C}$ : 形成層近傍の二次師部の蛍光分離画像形成層近傍の師部で顆粒状 の TPIが存在

$\mathrm{Xy}$ : 木部, $\mathrm{Ca}$ : 形成層, $\mathrm{Ra}$ : 放射柔組織, $\mathrm{Ph}$ : 師部, $\mathrm{Co}$ : 皮層, St : 師管, TPI : 黄色, 粒子状脂溶性物質 : 赤紫色, 細胞壁 : 青色 Reprinted with permission form Planta 238, 549, (2013). Copyright 2013 Springer International Publishing AG.
た液体である. トチュウのTPIについて, 形成層近傍の乳 管細胞では, 生合成初期の顆粒状 TPI として局在（図５Ｃ） が観察された。この点でラテックスの RPとの類似性を示 した.

二次師部の接線面観察は，横断面と同様に形成層近傍の 若い二次師部では顆粒状TPIの局在が観察された(図6AC). 一方，表皮側へと移行した古い二次師部では繊維状の TPIに変化することが観察された（図6D）。これらの観察 結果から, 形成層近傍で顆粒状のTPIが産生され蓄積し, 表皮側へと移行するとともに顆粒TPIが融合し, 最終的に 繊維状のTPIが形成され乳管細胞内を満たしていると考察 した。また, トチュウ由来TPIはDe Barry（1884） ${ }^{6)}$ の報 告と同じく無節乳管細胞に蓄積することが観察された.

この観察結果から，形成層から表皮側へと移行するとと もに乳管細胞は細胞間隙を伸張して生長し, やがて乳管細 胞の原形質はTPIに満たされ飽和する。 その際に, TPI生 合成機能や乳管細胞自体の成長能力を消失していると考え られる。これらの観察結果はWeissら（1892） ${ }^{14)}$ の報告と 一致している。 また, WeissとTian らが報告しているよう に(Weiss ら 1892) ${ }^{14)}$; Tian ら (1990) ${ }^{16)}$, 発生直後の乳 管細胞の伸長速度が著しく速いために, 本研究では乳管細 胞の始原細胞の確認は困難であった。 また, 形成層から乳 管細胞を発生させるトリガーも不明である.

トチュウの乳管細胞発生初期に存在する顆粒状TPIにつ いてTEMによる観察を行った。 顆粒状TPIは, 電子密度 


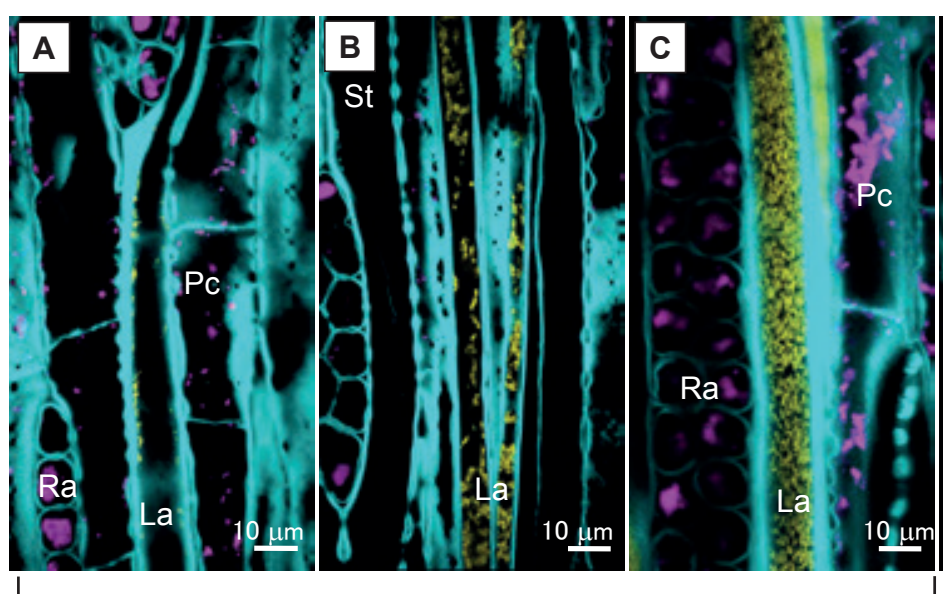

形成層近傍

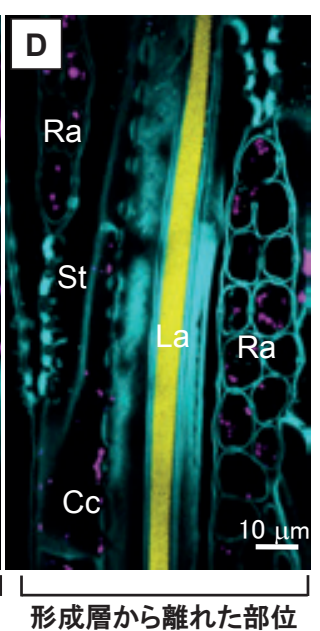

図6 トチュウ師部の接線面のTPI局在

$\mathrm{A}$ ：形成層近傍の乳管細胞接線面の蛍光分離画像顆粒状TPIが無節乳管周辺部より発生した状況

B : 形成層近傍より表皮側に若干移行した二次師部接線面の蛍光分離画像顆粒状TPIが無節乳管細胞の膜周辺部から内部へ充填されている状況

C : 形成層近傍より更に表皮側に移行した二次師部接線面の蛍光分離画像顆粒状TPIが無節乳管細胞内で飽和している状況

$\mathrm{D}$ : 表皮側の二次師部接線面の蛍光分離画像無節乳管細胞内にTPIが融合して纎維状で充満された状況

$\mathrm{Xy}$ : 木部, $\mathrm{Ca}$ : 形成層, $\mathrm{Ra}$ ：放射柔組織, $\mathrm{Ph}$ ：師部, $\mathrm{Co}$ ：皮層, St : 師管, TPI : 黄色, 粒子状脂溶性物質 : 赤紫色, 細胞壁 : 青色

Reprinted with permission form Planta 238, 549, (2013). Copyright 2013 Springer International Publishing AG.

が高く電子顕微鏡下で黒く観察されることから，一層の膜 構造で覆われていることを示した（図7A，B）.

Cornishら (1999） ${ }^{17)}$ は, TEM解析とスピンラベル法によ り, Euphorbia lactiflua, Ficus elastica, Parthenium argentatum, Hevea brasiliensisの 4 種のラテックス生産植物にお けるRPの物理的特性について, 一層のリン脂質膜に覆わ れていると報告している。トチュウのTEM観察結果は Cornish らの報告と同じく, 顆粒状 TPIはRP と同様の構造 と考えられる。 また, Cornishら (1999） ${ }^{17)}$ は, ラテック ス中のCPIのRPは表面が負に帯電し癒着を防止していると 考察している。しかし，トチュウのTPIは疎水性であるた め顆粒状TPIは，油滴の融合と同じく連続的に融合するこ

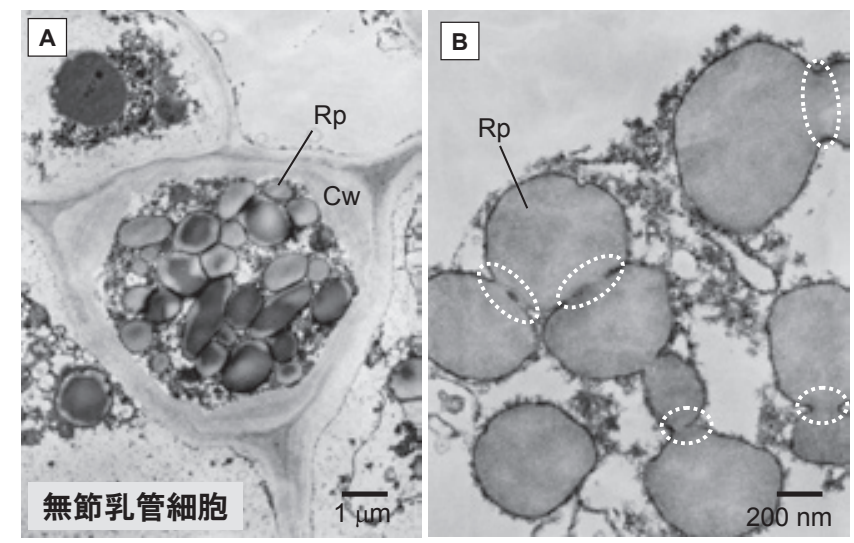

図7 無節乳管細胞内の顆粒状 TPI 横断面の TEM 画像

A : 顆粒状TPIの無節乳管細胞全体像 (5K 倍)

B：顆粒状 TPIの融合状況（20K 倍）

TPI接合部位（点線で囲んだ部位）の膜構造は消失

$\mathrm{Tp}$ : TPI, $\mathrm{Cw}$ ：細胞壁， $\mathrm{La}$ ：無節乳管細胞（横断面）

Reprinted with permission form Planta 238, 549, (2013). Copyright 2013 Springer International Publishing AG.
とで肥大化すると考察された。接合部分の膜構造はこの時 に消失されると考察した（図7B).

\subsection{3 トチュウTPIの産生・蓄積機構}

遺伝子解析（著者ら 2012） ${ }^{12)}$ SCLSM およびTEM（著者 ら 2013） ${ }^{13)}$ の結果から, TPIの産生・蓄積機構の推定モデ ルを図7に示した。発生部位は頂端分裂組織および形成層 のL2層からTPI生合成能を有する無節乳管細胞が不規則に 発生し細胞間隙の間を伸長する（図8A Stage 1)。続いて, 無節乳管細胞の細胞壁面から顆粒状 TPIの生成がみられ, TPIの蓄積が開始される (図8A Stage 2)。最終的に, 無節 乳管細胞内にて顆粒状TPIが融合を繰り返し, 接合面の膜 構造が消失する (図7B). この段階で, 疎水系のTPIは化 学的に融合が促進すると考察される。そして，細胞間隙の
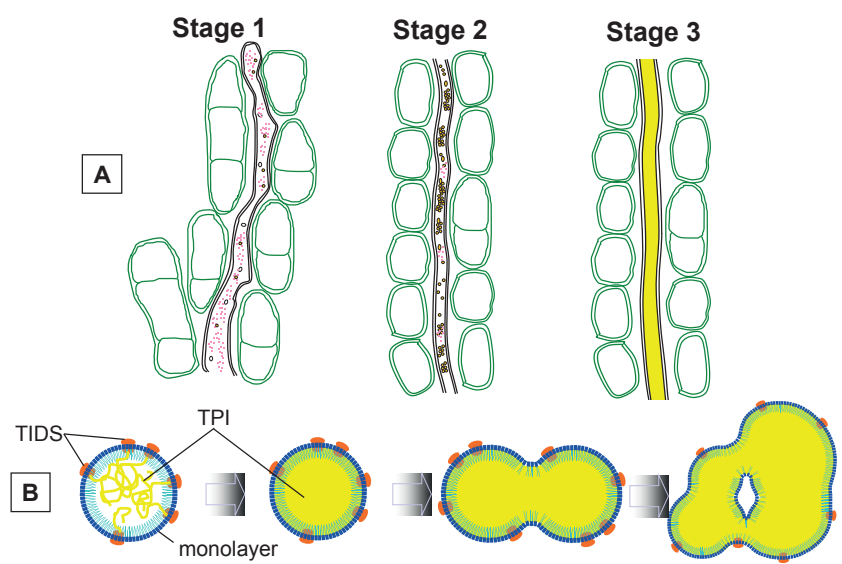

図 8 トチュウの無節乳管に生産するTPIの蓄積機序（推定モデル）

A : 無節乳管の伸長と TPIの蓄積 $($ Stage1 〜 3)

B : TIDSの局在と顆粒状TPIの生成と癒合状況

Reprinted with permission form Planta 238, 549, (2013). Copyright 2013 Springer International Publishing AG. 
間に形成された無節乳管細胞の形態に合わせたレプリカと して繊維状TPI として目視できると推定される（図8A Stage 3).

著者ら（2012） ${ }^{12 ）}$ の報告したTIDSは顆粒状TPIの表面 上に局在し, TPI生合成に関与する推定モデルを図 8Bに示 した。顆粒状TPIの表面に形成された脂質一重膜にTIDS は局在していると考えられる. 顆粒状TPIの融合が進行し, 繊維状TPIの形成は生合成というょり，無節乳管細胞内で の化学反応であると考えられる。繊維状TPIが細胞内に充 填されると，脂質膜の消失により TIDSの活性は失いTPI の生合成は自動的に停止すると示唆された。

\section{3 トチュウ乳管細胞の考察}

トチュウにおける無節乳管細胞へのTPI蓄積機序につい て，バイオイメージングにより繊維状 TPI形成の全容を解 析に成功した。今回は, 師部組織のTPI蓄積機序について 述べたが，トチュウの場合，重要な器官は師部組織ではな く，種子の果皮部に極端に多くTPIを含有する無節乳管細 胞の発生が重要である。これは種子保護を兼ねた防御のひ とつとも考えられるが，種子の乾燥重量の約 2 割を締める 量となる。このように産業的に成立する器官の乳管細胞の 発生とTPIの蓄積機序の解析は, バイオマス産業において 重要なテーマである.

\section{4. 乳管細胞のバイオイメージング}

本手法はパラゴムノキやトチュウに限るものではなく (参考例：グアユール (著者ら 2017） ${ }^{18)}$ )，植物の組織内に 多量に蓄積するオイルボディや樹脂等，天然ゴム以外の脂 溶性物質の局在解析にも応用できる技術である。また，乳 管細胞は疎水系化合物を植物に生育障害を起こすことなく 蓄積できる重要な器官の役割を果たしていることも注目で きることから，天然ゴム，樹脂，エラストマーなどバイオ マスを使った産業強化に資する技術のひとつとして普及し たい.
謝辞

本研究はNEDO補助事業にて推進した結果である。研究 を推進した林達史氏（現在積水化学(株)), 武田強氏（現在帝 人(株), 山東智紀博士（当時ブリヂストン(株)，渡辺信江氏 (ブリヂストン(株)), 日立造船(株)の各位, 大阪大学名誉教授 小林昭雄博士をはじめとする多くの方に感謝申し上げま す.

\section{Reference}

1 ) Meunier, A. L'appareil Lalicifère des Caoutchoutiers, Imprimerie Ind. et Fin., Bruxelles, 1912.

2) Vischer W. Verh. Naturforsch. Ges. Basel 1923, 35, 174

3 ) Riches J.P., Gooding E.G.B, New Phytol. 1952, 51, 1.

4) Nicole M, Geiger JP, Nandris D. J. Phytopathology, 1986 116, 259.

5 ) Sando T.; Hayashi T.; Takeda T.; Akiyama Y.; Nakazawa Y.; Fukusaki E; Kobayashi A, Planta, 2009 230, 215

6 ) De Barry A,; Vergleichende Anatomie der Vegetationsorgane der Phanerogamen und Farne. W. Engelmann, Leipzig, 1884.

7 ) Fahn A.; Laticifers. In Secretory tissues in plants. Academic press, London, 1979, pp223.

8 ) Xiu-Qian Z.J. Nat. Rubb. Res. 1987, 2, 94

$9)$ Hebant C. Can. J. Bot. 1981, 59, 974. In Frence.

10) Frey-Wyssling, A. Arch. v. d. Rubbercult. Nederlandsch-Indie 1930, 74, 135.

11) Hebant C.; Fay E. Z. Pfanzenphysiol, 1980, 97, 391.

12) Suzuki N.; Uefuji H.; Nishikawa T.; Mukai Y.; Yamashita A.; Hattori M.; Ogasawara N.; Bamba T.; Fukusaki E.; Kobayashi A.; Ogata y.; Sakurai N.; Suzuki H.; Shibata D.; Nakazawa Y. Planta, 2012, 236, 1405 .

13) Nakazawa Y.; Takeda T.; Suzuki N.; Hayashi T.; Harada Y.; Bamba T. Planta, 2013, 238, 549.

14) Weiss, F. E., Linnean Soc. London 2nd ser. Botany, 1892, 2, 3, 243

15) Kekwick R. G.; Latex and laticifers. Encyclopedia of Life Sciences, Wiley, 2002.

16) Tan, B. L.; Sarafis, V.; Beattie, G. A. C.; White, R.; Darley, E. M. J. Experim. Botany, 2005, 56, 420, 2755.

17) Cornish K.; Wood D. F.; Windle J. J. Planta, 1999, 210, 1, 85

18) Kajiura H., Suzuki N., Mouri H., Watanabe N., Nakazawa Y., Planta, 2017, 247, 513. 